\title{
SYNTHESIS OF 2-METHOXY-4,6-DI(PROP-1-ENYL) PHENOL FROM EUGENOL AND ITS ACTIVITY AS AN ANTIOXIDANT
}

\author{
Hernawan ${ }^{1,2,}$, Bambang Purwono ${ }^{2}$, and Tutik Dwi Wahyuningsih ${ }^{2}$ \\ ${ }^{1}$ Technical Implementation Unit for Development of Chemical Engineering Processes, Indonesian Institute of Sciences, \\ Gading, Playen, Gunungkidul, Yogyakarta, Indonesia 55861 \\ ${ }^{2}$ Department of Chemistry, Faculty of Mathematics and Natural Sciences, Universitas Gadjah Mada, \\ Sekip Utara, Yogyakarta, Indonesia 55281
}

Received January 2, 2012; Accepted March 27, 2012

\begin{abstract}
Synthesis and antioxidant activity of 2-methoxy-4,6-di(prop-1-enyl) phenol from eugenol have been investigated. Synthesis was conducted through three stages of reaction. The first step was CTAB micellar catalytic O-allylation reaction at room temperature, to give 4-allyl-1-(allyloxy)-2-methoxybenzene (2). Compound (2) was subsequently heated for Claisen rearrangement and produced 2,4-diallyl-6- methoxyphenol (3). The final steps was isomerization of compound (3) in alkaline conditions in ethylene glycol, to yield 2-methoxy-4,6-di(prop-1-enyl) phenol (4). Antioxidant activity test was conducted by TBARS and DPPH methods. TBARS test showed that the compound (4) at a concentration of $50 \mu \mathrm{M}$ could inhibit the oxidation of linoleic acid shown by the increasing of time lag phase (96 $\pm 2.94 \mathrm{~min}$ ), reducing the rate of propagation ( $\pm 54.54 \%$ ) and reducing of malonal dialdehyde (MDA) formation (68.04 $\pm 0.84 \%)$. The DPPH test revealed that compound (4) indicated DPPH free radical scavenging activity with $I C_{50} 107.66 \mu \mathrm{M}$ and comparable with $I C_{50}$ for $B H T 107.37 \mu M$.
\end{abstract}

Keywords: Claisen rearrangement; DPPH; eugenol; isomerization; O-allylation

\section{ABSTRAK}

Sintesis dan uji aktivitas antioksidan senyawa 2-metoksi-4,6-di(prop-1-enil) fenol dari eugenol telah diteliti. Sintesis dilakukan melalui tiga tahap reaksi. Tahap pertama dilakukan reaksi O-alilasi terkatalisis misel CTAB terhadap eugenol pada suhu ruangan diperoleh 4-alil-1-(aliloksi)-2-metoksibenzena (2). Senyawa (2) selanjutnya dipanaskan dengan mengalami penataan ulang Claisen dan diperoleh 2,4-dialil-6-metoksifenol (3). Tahap akhir dilakukan isomerisasi dalam kondisi basa dalam pelarut etilen glikol terhadap senyawa (3) diperoleh 2-metoksi-4,6di(prop-1-enil) fenol (4). Uji aktivitas antioksidan dilakukan dengan metode TBARs dan DPPH. Hasil uji TBARs menunjukkan bahwa senyawa (4) pada konsentrasi $50 \mu \mathrm{M}$ mampu menghambat oksidasi asam linoleat yang ditunjukkan dengan peningkatan waktu Lag phase (96 $\pm 2,94$ menit), memperlambat laju propagasi ( $\pm 54,54 \%)$ serta menghambat laju pembentukan $[M D A]_{\text {maks }}(68,04 \pm 0,84 \%)$. Hasil uji DPPH menunjukkan bahwa senyawa (4) mempunyai aktivitas anti radikal bebas dan mempunyai $I C_{50} 107,66 \mu M$ yang setara dengan $I C_{50} B H T 107,37 \mu M$.

Kata Kunci: penataan-ulang Claisen; DPPH; eugenol; isomerisasi; O-alilasi

\section{INTRODUCTION}

Oxidative stress, caused by an imbalance between antioxidant systems and the production of oxidants, seems to be associated with many diseases, especially cancers, cardiovascular diseases and inflammatory disorders [1]. The mechanisms by which these pathologies grow generally involve oxidative alteration of physiologically critical molecules, including proteins, lipids, carbohydrates, and nucleic acids, along with the modulation of gene expression and inflammatory response [2]. Many researchers now contemplate the use of antioxidant treatments as a key strategy for inhibiting or reversing the process of carcinogenesis [3]. Therefore, the search for potent antioxidants from natural resources, especially from plants sources as nutritional supplement, healthy food, and phytomedicine has become an important research issue at a world-wide level [4].

Antioxidant components are micro constituents in the diet that can delay or inhibit lipid oxidation by inhibiting the initiation or propagation of oxidizing chain reactions. They are also involved in scavenging free radicals. Natural antioxidants are usually secondary metabolites that can be classified as phenolic compounds. Phenols are reported to have an important

* Corresponding author. Tel/Fax : +62-274- 392570/391168

Email address : hern001@lipi.go.id

Hernawan et al. 
role to stabilize lipid peroxidation and associated with a wide range of biological activity including antioxidant properties [5] due to their redox properties, as reducing agent, or hydrogen atom donors.

Eugenol is one of the secondary metabolites found mainly in plants of cloves (Eugenia caryophyllata Thumb). Eugenol as phenolic compounds is potentially used as an antioxidant. It is used widely in applications ranging from perfumeries, flavoring, and medicines [6]. Some eugenol derivatives have been synthesized to increase their antioxidant properties. Nur'aini et al. [7] prepared Mannich derivatives, Hidalgo et al. [8] synthesized acetic ester derivatives, glycoside derivatives have been produced by Tominaga et al. [9], while Mastelic [1] prepared the hydroxyl methyl derivatives of eugenol. However those results have not revealed significant improvement. One of the eugenol derivatives were thought to have excellent antioxidant activity was 2-methoxy-4,6-on (prop-1-enyl) phenol. Two groups of prop-1-enyl is an electron donating. The group will push the electrons towards the aromatic ring of phenol and also be involved in the delocalization of electrons to make more stable aromatic ring. Therefore radical antioxidants could become increasingly unreactive. Based on this prediction prompted us to synthesize 2-methoxy-4,6-di(prop-1-enyl) phenol (4) from eugenol and evaluate its antioxidant activity.

\section{EXPERIMENTAL SECTION}

\section{Materials}

Eugenol (2-methoxy-4-(2-propenyl) phenol) (Sigma). Isoeugenol (Indesso) and linoleic acid (Calbiochem). Allyl alcohol 99\%, ethylene glycol, $\mathrm{N}$ cetyl- $N, N, N$ - trimethyl ammonium bromide (CTAB), $\mathrm{NaOH}, \mathrm{HCl} 37 \%$, dimethylformamide (DMF), diethyl ether, methanol, dichloromethane, Tween 80 , anhydrous $\mathrm{MgSO}_{4}$, anhydrous $\mathrm{Na}_{2} \mathrm{SO}_{4}$, thiobarbituric acid (TBA), 1.1-diphenyl-2-picrylhydrazyl (DPPH), phosphate buffer $\mathrm{pH} 7, \mathrm{CuSO}_{4}, \mathrm{EDTA}$, and butylated hydroxytoluene $(\mathrm{BHT})$ were purchased from Merck. All reagents and solvents were of analytical grade and used without purification.

\section{Instrumentation}

Infrared spectra were recorded with Shimadzu Prestige-21 FTIR Spectrometer. ${ }^{1} \mathrm{H}$ and ${ }^{13} \mathrm{C}-\mathrm{NMR}$ spectra were obtained on JEOL JN ECA -500 $(500 \mathrm{MHz})$. Mass spectra were recorded on Shimadzu GCS QP-2010S. Antioxidant and inhibitory activities assay were carried out using Dynamica RB 10 Ultraviolet-visible Spectrophotometer.

\section{Procedure}

\section{Synthesis of 4-allyl-1-(allyloxy)-2-methoxybenzene} (2)

A mixture of eugenol $(1,16.4 \mathrm{~g}, 0.1 \mathrm{~mol}), \mathrm{NaOH}$ (6 g, $0.15 \mathrm{~mol})$, dichloromethane $(50 \mathrm{~mL})$, CTAB $\left(1.21 \times 10^{2} \mathrm{mM}\right)$, and distilled water $(50 \mathrm{~mL})$ were placed in $500 \mathrm{~mL}$ round bottom flask. Allyl bromide $(24.2 \mathrm{~g}, 0.2 \mathrm{~mol})$ was added drop wise and the mixture was then stirred at room temperature for $5 \mathrm{~h}$. After completion, the organic layer was separated and aqueous layer was extracted with dichloromethane $(2 \times 20 \mathrm{~mL})$. The combined organic phase was washed with distilled water $(2 \times 50 \mathrm{~mL})$, dried with anhydrous $\mathrm{Na}_{2} \mathrm{SO}_{4}$ and concentrated to give compound (2) $(16.60 \mathrm{~g}, 81.10 \%)$ as yellowish liquid. $v_{\max }: 3078$, 2908-2839, 1843, 1589 and 1512, 1458, 1419, 1226 and $1141,995,918,856$ and $739 \mathrm{~cm}^{-1}$. ${ }^{1} \mathrm{H}-\mathrm{NMR}$ spectrum $\left(500 \mathrm{MHz}, \mathrm{CDCl}_{3}\right): \delta 6.71 \mathrm{ppm}(3 \mathrm{H}, \mathrm{m}, \mathrm{ArH})$, $5.95(2 \mathrm{H}, \mathrm{m},=\mathrm{CH}), 5.26\left(2 \mathrm{H}, \mathrm{m},=\mathrm{CH}_{2}\right), 5.05(2 \mathrm{H}, \mathrm{t}$, $\left.=\mathrm{CH}_{2}\right), 4.57\left(2 \mathrm{H}, \mathrm{d}, \mathrm{CH}_{2} \mathrm{O}\right), 3.81\left(3 \mathrm{H}, \mathrm{s}, \mathrm{OCH}_{3}\right)$, and $3.31\left(2 \mathrm{H}, \mathrm{d}, \mathrm{CH}_{2}\right) .{ }^{13} \mathrm{C}-\mathrm{NMR}$ spectrum $(125 \mathrm{MHz}$, $\left.\mathrm{CDCl}_{3},\right): \delta 39.80\left(\mathrm{CH}_{2}\right), 55.81\left(\mathrm{OCH}_{3}\right), 69.96\left(\mathrm{OCH}_{2}\right)$, 115.61 and $117.739\left(\mathrm{CH}_{2}=\right), 133.55$ and 137.629 $(=\mathrm{CH}), 112.20,113.58,120.33,133.03,146.30$ and 149.36 (ArC). Mass spectrum (El): $\mathrm{m} / \mathrm{z} 204$ (M, 40\%), 163 (100), 135 (15), 103 (70), 91 (50), 77 (23), 41 (70).

\section{Synthesis of 2,4-diallyl-6-methoxyphenol (3)}

Into $100 \mathrm{~mL}$ round bottomed flask equipped with magnetic stirrer, a thermometer, and condenser, compound (2) $(10.2 \mathrm{~g}, 0.05 \mathrm{~mol})$ in DMF $(20 \mathrm{~mL})$ were stirred until dissolved and the mixture was then heated at $160{ }^{\circ} \mathrm{C}$ for $8 \mathrm{~h}$. After cooling, $50 \mathrm{~mL}$ of ice water was added and stirred for another $15 \mathrm{~min}$. Then, the mixture was extracted with diethyl ether $(3 \times 25 \mathrm{~mL})$ and the combined organic layer was washed successively with water $(4 \times 50 \mathrm{~mL}), \mathrm{HCl} 2 \mathrm{M}(4 \times 50 \mathrm{~mL})$, saturated $\mathrm{NaHCO}_{3}(4 \times 50 \mathrm{~mL})$ and saturated $\mathrm{NaCl}(50 \mathrm{~mL})$. The organic extracts dried with anhydrous $\mathrm{Na}_{2} \mathrm{SO}_{4}$ and the solvent was evaporated to yield the diallyl compound (3) $(9.70 \mathrm{~g}, 95.10 \%)$ as yellowish clear liquid. $v_{\text {max }}$ : $3525,3078,2908-2839,1828,1612$ and 1496, 1436, 1365, 1288 and 1072, 995, $910 \mathrm{~cm}^{-1} .{ }^{1} \mathrm{H}-\mathrm{NMR}$ spectrum $\left(500 \mathrm{MHz}, \mathrm{CDCl}_{3}\right): \delta 6.78(2 \mathrm{H}, \mathrm{d}, \mathrm{ArH})$, $6.07(2 \mathrm{H}, \mathrm{m},=\mathrm{CH}), 5.82(1 \mathrm{H}, \mathrm{s}, \mathrm{OH}), 5.15(4 \mathrm{H}, \mathrm{m}$, $\left.=\mathrm{CH}_{2}\right), 3.94\left(3 \mathrm{H}, \mathrm{s}, \mathrm{OCH}_{3}\right)$, and $3.41\left(4 \mathrm{H}, \mathrm{dd}, \mathrm{CH}_{2}\right)$. ${ }^{13} \mathrm{C}-\mathrm{NMR}$ spectrum $\left(125 \mathrm{MHz}, \mathrm{CDCl}_{3}\right.$ ): $\delta 33.96$ and $40.01\left(\mathrm{CH}_{2}\right), 55.92\left(\mathrm{OCH}_{3}\right), 115.44$ and $115.38\left(\mathrm{CH}_{2}=\right)$, 136.80 and $137.98(=\mathrm{CH}), 109.04,122.10,125.65$, $131.08,141.65$, and $146.33(\mathrm{ArC})$. Mass spectrum (EI): m/z 204 (M, 100\%), 189 (10), 173 (15), 131 (70), 115 (30), 103 (50), 91 (35), 77 (20). 


\section{Synthesis of 2-methoxy-4,6-di(prop-1-enyl)phenol (4)}

To $100 \mathrm{~mL}$ three necks round bottomed flask equipped with a thermometer and a set of reduced pressure distillation unit were placed $\mathrm{KOH}(10.5 \mathrm{~g})$ and ethylene glycol $(40 \mathrm{~mL})$. The mixture was stirred and heated to dissolve all the bases. After cooling, compound (3) $(6.12 \mathrm{~g}, 0.03 \mathrm{~mol})$ was added to the flask and the mixture was heated at $125^{\circ} \mathrm{C}$ for $1 \mathrm{~h}$. Distillate that comes out (water) was collected. Reaction was continued with reflux at $150{ }^{\circ} \mathrm{C}$ for $6 \mathrm{~h}$. The mixture was cooled, diluted with distilled water $(100 \mathrm{~mL})$, and then acidified to $\mathrm{pH} 2-3$ with $\mathrm{HCl} 25 \%$. The mixture was extracted with diethyl ether, dried with anhydrous $\mathrm{MgSO}_{4}$ and concentrated to give the product (4) (5.24 g, $85.62 \%)$ as brown liquid. $v_{\max }: 3518,3008,2931-2854$, 1597, 1373, 1280 and $1080 \mathrm{~cm}^{-1}$. ${ }^{1} \mathrm{H}-\mathrm{NMR}$ spectrum $\left(500 \mathrm{MHz}, \mathrm{CDCl}_{3}\right): \delta 6.96(1 \mathrm{H}, \mathrm{s}, \mathrm{ArH}), 6.75(1 \mathrm{H}, \mathrm{s}, \mathrm{OH})$, $6.70(1 \mathrm{H}, \mathrm{d}, \mathrm{ArCH}), 6.34(1 \mathrm{H}, \mathrm{d}, \mathrm{ArCH}), \delta 6.12(2 \mathrm{H}, \mathrm{t}$, $\mathrm{ArH}$ and $=\mathrm{CH}), 5.89(1 \mathrm{H}, \mathrm{t},=\mathrm{CH}), 3.86\left(3 \mathrm{H}, \mathrm{s}, \mathrm{OCH}_{3}\right)$, $1.93\left(6 \mathrm{H}, \mathrm{d}, \mathrm{CH}_{3}\right) .{ }^{13} \mathrm{C}-\mathrm{NMR}$ spectrum $(125 \mathrm{MHz}$, $\left.\mathrm{CDCl}_{3},\right): \delta 18.43$ and $19.03\left(\mathrm{CH}_{3}\right), 56.05\left(\mathrm{OCH}_{3}\right), 124.03$ and 126.94 $(\mathrm{CH}=), 125.24$ and $131.01(\mathrm{ArCH}=), 105.94$, $116.95,123.37,129.74,141.82,146.76(\operatorname{ArC})$. Mass spectrum (EI): m/z 204 (M, 100\%), 189 (10), 161 (15), 128 (20), 115 (20), 91 (20), 77 (15), 43 (35).

\section{Antioxidant activity assay using the TBARS}

Antioxidant activity assay using the TBARS method according Esterbauer [10]. Linoleic acid $(7.5 \mu \mathrm{M})$ was emulsified with Tween $80(0.1 \%, v / v)$ in $10 \mathrm{mM}$ phosphate buffer $\mathrm{pH} 7.0$ with samples of antioxidants (BHT, 2-methoxy-4,6-di(prop-1-enyl) phenol (4), 2,4-diallyl-6-methoxyphenol (3), isoeugenol and eugenol) $(50 \mu \mathrm{M})$. Oxidation was initiated by addition of $10 \mu \mathrm{M}$ freshly prepared $\mathrm{CuSO}_{4}$, and stopped by cooling in ice bath in the presence of $100 \mu \mathrm{M}$ EDTA and $20 \mu \mathrm{M}$ $\mathrm{BHT}$. The absorbance reading were measured every $15 \mathrm{~min}$, over $150 \mathrm{~min}$ at $37{ }^{\circ} \mathrm{C}$ in UV-Vis Spectrophotometer. Control was incubated alone without antioxidant samples. \% inhibition is determined as:

$\%$ Inhibition $=\frac{A_{c}-A_{s}}{A_{c}} \times 100$

where $A_{c}$ is absorbance of the control, and $A_{s}$ is absorbance of the treated sample.

The peroxidation kinetic parameters: lag time $(\mathrm{min})$, maximal rate of oxidation ( $\mathrm{nM} / \mathrm{min})$, and maximal amount of $\mathrm{CD}$ formation $(\mu \mathrm{M})$ were calculated using molar extinction coefficient of $29.500 \mathrm{M}^{-1} \mathrm{~cm}^{-1}$

\section{Inhibitory activity test of free radicals}

Inhibition of free radical activity were measured against radical 1.1-diphenyl-2-picrylhydrazyl (DPPH) using the method of Yang [11]. For each antioxidant samples (BHT, 2-methoxy-4,6-di(prop-1-enyl) phenol (4), 2,4-diallyl-6-methoxyphenol (3), eugenol, and isoeugenol) were made in different concentrations began to 20-240 $\mu \mathrm{M}$ in methanol. Reaction mixture consisted of a sample $(100 \mathrm{~mL})$ and $\mathrm{DPPH}$ radical $(100 \mathrm{~mL}, 0.2 \mathrm{mM}$ in methanol) were shake and left for $30 \mathrm{~min}$ in the dark room. Absorbance was measured at $\lambda 517 \mathrm{~nm}$.

Absorbance is used to determine the $\%$ inhibition $\%$ Inhibition $=\left[1-\frac{A_{s}}{A_{0}}\right] \times 100$

where $A_{c}$ is absorbance of the control, and $A_{s}$ is absorbance of the treated sample.

\section{RESULT AND DISCUSSION}

\section{Synthesis of 4-allyl-1-(allyloxy)-2-methoxybenzene (2)}

Compound of 4-allyl-1-(allyloxy)-2-methoxy benzene (2) was synthesized by CTAB catalyzed O-allylation of eugenol with allyl bromide in dichloromethane-water biphasic systems. The allyl bromide was previously prepared from allyl alcohol and hydrogen bromide by the method of Kamm and Marvel [12]. Reaction was carried out at room temperature in the presence of $\mathrm{NaOH}$ without heating to avoid direct product of Claisen rearrangement to yield 4-allyl-1(allyloxy)-2- methoxy-benzene (2) as yellowish liquid in $81.10 \%$ yield.

Clear evidence of allyloxy compound (2) was given by IR spectrum, which demonstrated the absence of hydroxy frequency in the range $3400-3500 \mathrm{~cm}^{-1}$ of the starting eugenol. It is indicates that the reaction of O-allylation certainly take place effectively at room temperature in the presence of $C T A B$ as micellar catalyst and no direct product of Claisen rearrangement.

The vinylidene allyloxy protons were found in ${ }^{1} \mathrm{H}$-NMR spectra of compound (2) as a multiplet at $5.26 \mathrm{ppm}$ and these protons were shifted downfield with respect to $5.05 \mathrm{ppm}$ in the vinylidene allyl due to the electron withdrawing of oxygen atom. In addition, the presence of the two protons appearing as doublets at $4.57 \mathrm{ppm}$ confirmed the $\mathrm{OCH}_{2}$ groups. The ${ }^{13} \mathrm{C}-\mathrm{NMR}$ spectrum demonstrated thirteen peaks corresponding to thirteen carbon and this spectrum displayed signals at $69.96,137.62$ and $117.73 \mathrm{ppm}$ originating from the corresponding $\mathrm{OCH}_{2},=\mathrm{CH}$, and $=\mathrm{CH}_{2}$ carbons, respectively. Furthermore, the mass spectrum revealed a molecular ion peak at $\mathrm{m} / \mathrm{z} 204(40 \%)$ together with a base peak at $\mathrm{m} / \mathrm{z} 163$ resulting from the loss of the allyl group. The resulting structure (2), which is 4-allyl-1(allyloxy)-2-methoxy benzene is supported by all the spectroscopic data (Scheme 1). 


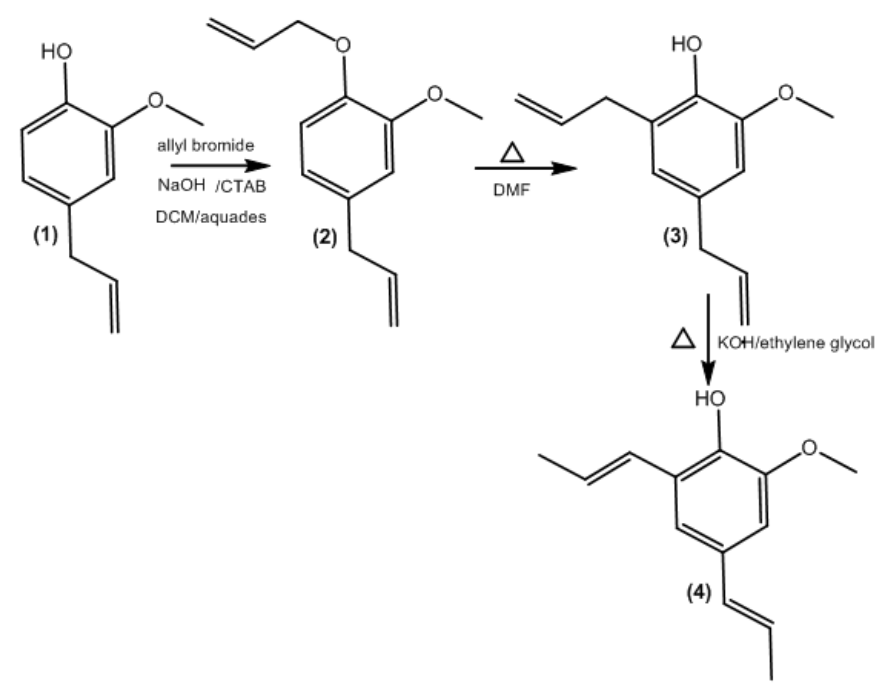

Scheme 1. Synthesis of 2-methoxy-4,6-di(prop-1-enyl) phenol (4)

\section{Synthesis of 2,4-diallyl-6-methoxyphenol (3)}

The compound of 4-allyl-1-(allyloxy)-2methoxybenzene (2) was then converted into 2,4-diallyl6-methoxy phenol (3) via Claisen rearrangement according Coombes and Moody [13] procedure. Synthesis was carried out by heating compound (2) in the DMF at $160{ }^{\circ} \mathrm{C}$ for $8 \mathrm{~h}$ to yield the diallyl compound (3) in $95.10 \%$ as yellowish clear liquid.

The Infrared spectrum of compound (3) showed a strong absorption in the region $3525 \mathrm{~cm}^{-1}$ for the hydroxy group and this indicates that Claisen rearrangement has taken place. The ${ }^{1} \mathrm{H}$-NMR spectrum displayed the existence of hydroxy proton as a singlet at $5.82 \mathrm{ppm}$, and two protons aromatic as a doublet at $6.78 \mathrm{ppm}$. These data clearly confirmed that the substitution of proton aromatics by an allyl group had occurred. In addition, all of the protons in both allyl groups appeared at the same resonance. The ${ }^{13} \mathrm{C}-\mathrm{NMR}$ spectrum also confirmed the existence of two allyl groups with carbon resonances of vinylidene carbons at 137 and $115 \mathrm{ppm}$ and two peaks of methylene at 40.01 and $33.96 \mathrm{ppm}$. While the mass spectra of compound (3) showed molecular ion at $\mathrm{m} / \mathrm{z} 204(100 \%)$ Finally, it can be concluded that the product compound (3) is 2,4-diallyl-6methoxy phenol (Scheme 1).

\section{Synthesis of 2-methoxy-4,6-di(prop-1-enyl)phenol (4)}

The final step to synthesis of 2-methoxy-4,6di(prop-1-enyl)phenol (4) is isomerisation reaction. Isomerisation was carried out according Kadarohman method [14]. Heating of compound (3) and $\mathrm{KOH}$ in the

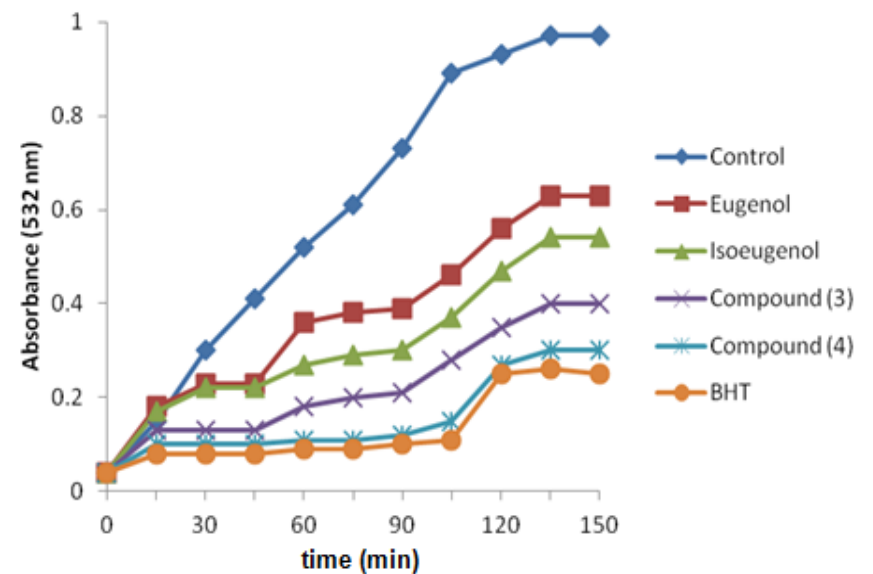

Fig 1. Effects of eugenol and it's derivatives on $\mathrm{Cu}^{2+}$ induced linoleic acid oxidation monitored by malonal dialdehyde (MDA) formation. Each point represents the mean of three replicates

ethylene glycol at $150{ }^{\circ} \mathrm{C}$ for $6 \mathrm{~h}$ gave the desired compound (4) as liquid in $85.62 \%$ yield.

Evidence for the structure of isomerisation product (4) was given by the ${ }^{1} \mathrm{H}-\mathrm{NMR}$ spectra, which demonstrated the presence of a singlet peak for hydroxy proton at $6.75 \mathrm{ppm}$ and a doublet peak at $1.93 \mathrm{ppm}$ corresponding to the six methyl protons. The ${ }^{13} \mathrm{C}-\mathrm{NMR}$ spectra also confirmed the existence of methyl groups with carbon resonances at 19.03 and $18.43 \mathrm{ppm}$. Even though the corresponding molecular ion was observed at $\mathrm{m} / \mathrm{z} 264(100 \%)$ similar to that of compound (3) in the mass spectrum, these assignments are consistent with infrared spectrum, which showed no frequency of vinylidene vibrations of compound (3) in the region of 990 and $910 \mathrm{~cm}^{-1}$. Therefore the isomerisation product is 2-methoxy-4,6di(prop-1-enyl)phenol (4) (Scheme 1)

\section{Antioxidant activity assay}

In order to evaluate the protective action of compound (4), we tested its effect on linoleic acid oxidation. Antioxidant activity of compound (4) was determined in the oxidation reaction of linoleic acid oxidation initiated by $\mathrm{Cu}_{2} \mathrm{SO}_{4}$ monitored by malonal dialdehyde (MDA) formation. MDA formation was assessed using Thiobarbituric Acid Reagent Substances (TBARS) and BHT was used as an antioxidant standard.

The results showed significant inhibition of linoleic acid oxidation as assessed by MDA formation, as shown in Fig. 1. The extends of inhibition of MDA formation was $68.06 \%$ at $50 \mu \mathrm{M}$, while $\mathrm{BHT}$ as standard antioxidant, at the same concentration gave $73.20 \%$. The effect on kinetic parameters of oxidation 
Table 1. Effects of eugenol and it's derivatives on $\mathrm{Cu}^{2+}$ induced linoleic acid oxidation monitored by malonal dialdehyde (MDA) formation.

\begin{tabular}{lcccc}
\hline \multirow{2}{*}{ Antioxidant } & \multicolumn{4}{c}{ Kinetics parameters } \\
\cline { 2 - 5 } & Lag Phase $(\mathrm{min})$ & Propagation Rate $(\mu \mathrm{M} / \mathrm{min})$ & {$[\mathrm{MDA}]_{\text {maks }}(\mathrm{mM})$} & \% inhibition $[\mathrm{MDA}]_{\text {maks }}$ \\
\hline BHT & $105 \pm 1.63$ & $29.50 \pm 0.14$ & $7.67 \pm 0.05$ & $73.20 \pm 0.85$ \\
Compound (4) & $96 \pm 2.94$ & $39.33 \pm 0.47$ & $9.14 \pm 0.18$ & $68.04 \pm 0.84$ \\
Compound (3) & $60 \pm 2.16$ & $62.07 \pm 1.17$ & $12.10 \pm 0.08$ & $57.73 \pm 0.84$ \\
Isoeugenol & $45 \pm 1.63$ & $74.53 \pm 0.60$ & $16.23 \pm 0.26$ & $43.30 \pm 0.85$ \\
Eugenol & $40 \pm 2.94$ & $78.23 \pm 0.39$ & $18.88 \pm 0.53$ & $34.02 \pm 0.84$ \\
Control & $15 \pm 1.47$ & $86.53 \pm 0.47$ & $28.62 \pm 0.17$ & 0 \\
\hline
\end{tabular}

Each value represents the mean of three replicates

Table 2. Effects of eugenol and it's derivatives on DPPH radical activity

\begin{tabular}{lrcccc}
\hline \multirow{2}{*}{ Sample } & \multicolumn{5}{c}{$\%$ Inhibition } \\
\cline { 2 - 6 } & \multicolumn{1}{c}{$40 \mu \mathrm{M}$} & $40 \mu \mathrm{M}$ & $80 \mu \mathrm{M}$ & $120 \mu \mathrm{M}$ & $240 \mu \mathrm{M}$ \\
\hline BHT & $15.46 \pm 0.42$ & $38.14 \pm 0.59$ & $46.39 \pm 0.08$ & $64.95 \pm 0.76$ & $86.60 \pm 0.45$ \\
Compound (4) & $12.37 \pm 0.41$ & $35.05 \pm 0.59$ & $48.45 \pm 0.25$ & $68.04 \pm 0.51$ & $88.66 \pm 0.68$ \\
Compound (3) & $15.46 \pm 0.76$ & $24.74 \pm 0.42$ & $30.93 \pm 0.17$ & $41.24 \pm 0.34$ & $51.55 \pm 0.75$ \\
Isoeugenol & $9.27 \pm 0.24$ & $17.53 \pm 0.34$ & $20.61 \pm 0.42$ & $28.87 \pm 0.51$ & $38.14 \pm 0.67$ \\
Eugenol & $7.22 \pm 0.67$ & $16.50 \pm 0.58$ & $19.59 \pm 0.51$ & $27.83 \pm 0.42$ & $32.99 \pm 0.41$ \\
\hline
\end{tabular}

Each value represents the mean of three replicates

(Table 1), showed that compound (4) prolonged the lag time $(\geq 96 \pm 2.94 \mathrm{~min})$, diminished the propagation rate $(54.54 \%)$, and inhibited the maximal amount of MDA formation $68.04 \pm 0.84 \%(50 \mu \mathrm{M})$.

Another test to confirm the antioxidant activity of compound (4), DPPH was used. DPPH is convenient method when radical scavenging abilities of compound are investigated. The results are presented in Table 2. The DPPH free radical scavenging results of the positive control and compound (4) are expressed as a percentage of inhibition. Based on the values calculated from the linearity curves, the compound (4) showed a higher scavenging percentage than that of compound (3), isoeugenol and eugenol. $\mathrm{IC}_{50}$ for compound (4) was 107.66 $\mu \mathrm{M}$ comparable with $\mathrm{IC}_{50}$ for $\mathrm{BHT} 107.37 \mu \mathrm{M}$.

The result of TBARS and DPPH methods for compound (4) has higher an antioxidant properties compared with compound (3), eugenol and isoeugenol. Antioxidant activity of phenols depends on electronic and steric effects of the ring, substituent and the strength of hydrogen bonding interaction between the phenol and the solvent [15-16]. The highest antioxidant properties of compound (4) possibly due to the presence of the two prop-1-enyl group, which gave a greater steric hindrance and allows the resonance with the aromatic ring to produce the stabilization of phenoxyl radicals.

\section{CONCLUSION}

The result indicated that synthesis of 2-methoxy4,6-di(prop-1-enyl) phenol (4) from eugenol could be obtained. Both antioxidant activity assays demonstrated that compound (4) has greatest antioxidant capacity compared with eugenol derivatives of compound (3) and isoeugenol. DPPH test revealed that compound (4) has
$\mathrm{IC}_{50} 107.66 \mu \mathrm{M}$, comparable with $\mathrm{IC}_{50}$ for $\mathrm{BHT}$ (107.37 $\mu \mathrm{M})$.

\section{ACKNOWLEDGEMENT}

The authors would like to express their gratitude to Head for Indonesian Institute of Sciences which gave fund to study and this research and Ir. Suharto, MT (UPT BPLM Lampung) for providing the eugenol.

\section{REFERENCES}

1. Mastelić, J., Jerković, I., Blažević, I., Poljak-Blaži, M., Borović, S., Ivančić-Baće, I., Smrecki, V., Žarković, N., Brčić-Kostić, K., Vikić-Topić, D., and Muller, N., 2008, J. Agric. Food Chem., 56, 11, 3989-3996.

2. Laguerre, M., Lecomte, J., and Villeneuve, P., 2007, Prog. Lipid Res., 46, 5, 244-282.

3. Shireqi, I., Reddy, P., and Brenner, D.E., 2000, Crit. Rev. Oncol. Hematol., 33, 3, 157-167.

4. Hernawan, 2007, Indo. J. Chem. 8, 1, 111-113.

5. Roginsky, V., 2003, Arch. Biochem. Biophys., 414, 2, 261-270.

6. Awasthi, P.K., Dixit, S.C., Dixit, N., and Sinha, A.K., 2008, J. Pharm. Res., 1, 2, 215-220

7. Nur'aini, Purwono, B., and Tahir, I., 2007, Indo. J. Chem., 7, 1, 61-66.

8. Hidalgo, M.E, De La Rosa, C., Carrasco, H., Cardona, W., Gallardo, C., and Espinoza, L., 2009, Quim. Nova, 32, 6, 1467-1470.

9. Tominaga, H., Kobayashi, Y., Goto, T., Kasemura, K., and Nomura, M., 2005, Yakugaku Zasshi, 125, $4,371-375$. 
10. Esterbauer, H., Striegl, G., Puhl, H., and Rotheneder, M., 1989, Free Radical Res., 6, 1, 6775.

11. Yang, H., Dong, Y., Du, H., Shi, H., Peng, Y., and Li, X., 2011, Molecules, 16, 4, 3444-3455.

12. Kamm, O., and Marvel, C.S., 1941, Org. Synth., 1, 25.

13. Coombes, C.L., and Moody, C.J., 2008, J. Org. Chem., 73, 17, 6758-6762.

14. Kadarohman, A., Sastrohamidjojo, $H$, and Muchalal, M., 1999, Study of the Complex Reaction Pathway of Eugenol Isomerization, Proceeding of $6^{\text {th }}$ National Seminar on Organic Chemistry, Department of Chemistry, Universitas Gadjah Mada, 24-25 September 1999.

15. Brigati, G., Lucarini, M., Mugnaini, V., and Pedulli, G.F., 2002, J. Org. Chem., 67, 4828-4832.

16. Snelgrove, D.W., Lusztyk, J., Banks, J.T., Mulder, P., and Ingold, K.U., 2001, J. Am. Chem. Soc., 123, 469-477. 